\title{
Psychological issues faced by Government School Teachers on upgradation of technological and teaching techniques with special reference to Kumbakonam
}

\author{
Suganthi.K, Umamaheshwari.D, Valli.T, Adhithya.N
}

\begin{abstract}
School teachers play a vital role in shaping the young minds, keeping them psychologically positive will feed the students' community. Psychological issues act a major role in work life management of all employees but it has a two way refection when it comes to teaching profession, this study focus on educational changes getting updated in government schools may bring sea level changes to the society, but these changes give emotions imbalance and psychological issues at work place. Mostly school teachers are affected both physically and emotionally in their work life. Tamil Nadu government pays more attention to improve the basic structure of government schools, by introducing technological updation and improved techniques in government schools, every individual student can get more knowledge. This article describes the psychological issues faced by government school teachers of Tamil Nadu.
\end{abstract}

Keywords: Emotions, Structure of government, teachers, schools.

\section{INTRODUCTION}

Teaching is noble, every year in India we are celebrating teachers' day on $5^{\text {th }}$ September to splendid their career and glorifying prospects of their job. These psychological issues lead to many problems like stress, irritability, Sleeping problems, blood pressure, headaches etc., Comparing with other social groups' school teachers face more mental stress and psychological issues. While knowing that they are to be demotion or transfer from the job position the government school teachers filled with psychological issues. This psychological stage results emotional and physical stress to government school teachers. This study is how Tamil Nadu government vision on government education affects government school teachers and force them into psychosomatic stage.

Revised Manuscript Received on July 05, 2019

Suganthi.K, Department of Commerce, Periyar Maniammai Institute of Science \& Technology, Thanjavur, India.

Umamaheshwari.D, Department of Commerce, Periyar Maniammai Institute of Science \& Technology, Thanjavur, India.

Valli.T, Department of Commerce, Periyar Maniammai Institute of Science \& Technology, Thanjavur, India.

Adhithya.N, Department of Commerce, Periyar Maniammai Institute of Science \& Technology, Thanjavur, India.
A. Objectives of the Study

* To study the psychological issues faced by government school teachers.

* To know the impact on practical difficulties and training methodologies of government school teachers.

B. Need for the study

* To know about the psychological issues of government school teachers.

* To study the teaching techniques and training provided to government school teachers.

\section{Limitations of the study}

* Studied only about government school teachers.

* Some of the teachers were not able to express their thoughts freely and individually.

* Focused only on government school teachers with reference to Kumbakonam.

\section{Statement of the problem}

New techniques of teaching to government schools are evolving in Tamil Nadu education system to improve the quality of education. As well as modern methods of teaching techniques are encouraging government teachers to learn new techniques and teach the students with their heart. But the government school teachers are not yet ready to adapt to the futuristic education module, thus they are facing psychological issues on handling day to day work and students. Government school teachers are forcing them to get into technological up gradation in education and to the new form of teaching methods. Tamil Nadu government pays more attention to improve the structure of government schools as well as their syllabus to make progress in education of government school students. Most of the government school teachers are attaining the psychosomatic stage while handling students.

\section{RESEARCH METHODOLOGY}

\section{A. Research Objective}

To measure the psychological issues faced by government school teachers on technological updating in school educations. 


\section{Psychological issues faced by Government School Teachers on upgradation of technological and teaching}

techniques with special reference to Kumbakonam

\section{B. Research Design}

This research adopted descriptive approach with a sample size of 40 from the Government school teachers at Kumbakonam. Simple random sampling technique was used to select the targeted samples. This research is mainly focused on the Government school teachers at Kumbakonam. Both primary and secondary data were used. Primary data were collected through questionnaires using random sampling method. The secondary data collected from the various unpublished records, books, journals, and websites.

\section{Variables}

Dependent variable is psychological issues of government school teachers

Independent Variables are emotional problems, support from family, work pressure, psychological issues, stress, sleeping problems, irritability.

\section{OF TEACHING APPROACH}

Teacher centered - The main source of knowledge in this approach is teacher centric or teacher oriented. Teachers are the persons who deliberately teach with their full efforts. Modern teaching technique focused through this teacher centric approach.

Students centered - The core basis of knowledge in this approach is student centric or student oriented. There is no possibility of learning when the students are not ready to study. Ancient techniques are fully focused this student centric approach.

\section{PSYCHOLOGICAL ISSUES ON GOVERNMENT SCHOOL TEACHERS}

The word psychology says that the uncontrollable feelings, thoughts and behaviour how far impact the individuality of a person. One of the most stressful and thoughtful job is teaching. Teachers are not only taught education they also make the students to choose their pathway in their life and act as a connection to fulfill the gaps between students and principal in government schools. In current situation government school teachers threatened by the new form of technology updating, since it pay pathway to termination or degrading their position by so they are feared about it. Mental health is more important to any type of workplace, while handling students and their parents' government school teachers struggled emotionally and physically. The break point of this emotional stage leads psychological issues to government school teachers. Psychological issues are related with physical issues, when comparing other jobs government school teachers are loaded with many works. They are forced to complete their task to keep the position or to get the promotion from one stage to another. That's why they are very stressful and incompetent to fulfill their job. These reasons show how the government school teachers are psychologically affected. Tamil Nadu government provided various camping to get the government school teachers out of the psychosomatic stage. But it is not far enough to face these situations by the government school teachers.

\section{TYPES OF PSYCHOLOGICAL ISSUES ON GOVERNMNET SCHOOL TEACHERS}

The Psychological barriers are also called as emotional barriers denotes the psychological stages like opinions, emotions, attitudes, consciousness of people that directly affects the competence to communicate with the students. The communication process is fully depends on psychological condition of a person. When a teacher is not psychologically sound, then they cannot make an effective communicate with the students and parents. Some psychological barriers in work life of government school teachers were lack of attention, premature evaluation, distress, loss of transmission. Another psychological barrier is work family balance, teachers faces many crises. These psychological issues lead to many problems in their workplace. Anxiety - It is a psychological stage resemble like fear, sleep problems, dry mouth and nausea. Usually every government school teacher attains this psychosomatic stage. Mood - Psychosomatic stage busted into irritability and mood swings.

Personality - This is a stage affects when the government school teachers abused through physically, sexually and emotionally.

\section{DATA ANASLYSIS}

\section{A. Impact of psychological issues faced by Government school teachers using Chi-square test}

(SA- Strongly agree A-Agree N- Neutral DA-Disagree SDA- Strongly disagree)

\begin{tabular}{|c|c|c|c|c|c|}
\hline Factors & SA & A & $\mathbf{N}$ & DA & SDA \\
\hline $\begin{array}{l}\text { Are you facing } \\
\text { emotional } \\
\text { problems due to } \\
\text { changes in } \\
\text { government } \\
\text { policies on } \\
\text { teaching up } \\
\text { gradation }\end{array}$ & $\begin{array}{c}25 \\
(50 \%)\end{array}$ & $\begin{array}{c}13 \\
(26 \%)\end{array}$ & $\begin{array}{c}6 \\
(12 \%)\end{array}$ & $\begin{array}{c}6 \\
(12 \%)\end{array}$ & $\begin{array}{c}0 \\
(0 \%)\end{array}$ \\
\hline $\begin{array}{l}\text { Are you feeling } \\
\text { psychologically } \\
\text { stressed on } \\
\text { degradation from } \\
\text { higher level } \\
\text { education to } \\
\text { lower level } \\
\text { education }\end{array}$ & $\begin{array}{c}7 \\
(14 \%)\end{array}$ & $\begin{array}{c}30 \\
(60 \%)\end{array}$ & $\begin{array}{c}10 \\
(20 \%)\end{array}$ & $\begin{array}{c}3 \\
(6 \%)\end{array}$ & $\begin{array}{c}0 \\
(0 \%)\end{array}$ \\
\hline $\begin{array}{l}\text { Are you forced to } \\
\text { follow your } \\
\text { higher officials } \\
\text { orders ( Principal, } \\
\text { Head of } \\
\text { Management) }\end{array}$ & $\begin{array}{c}9 \\
(18 \%)\end{array}$ & $\begin{array}{c}21 \\
(42 \%)\end{array}$ & $\begin{array}{c}16 \\
(32 \%)\end{array}$ & $\begin{array}{c}4 \\
(8 \%)\end{array}$ & $\begin{array}{c}0 \\
(0 \%)\end{array}$ \\
\hline $\begin{array}{l}\text { Are you getting } \\
\text { support from your } \\
\text { family on } \\
\text { psychological } \\
\text { issues due to work } \\
\text { pressure }\end{array}$ & $\begin{array}{c}6 \\
(12 \%)\end{array}$ & $\begin{array}{c}31 \\
(62 \%)\end{array}$ & $\begin{array}{c}10 \\
(20 \%)\end{array}$ & $\begin{array}{c}3 \\
(6 \%)\end{array}$ & $\begin{array}{c}0 \\
(0 \%)\end{array}$ \\
\hline
\end{tabular}




\begin{tabular}{|c|c|c|c|c|c|}
\hline $\begin{array}{l}\text { Are you facing } \\
\text { clashes between } \\
\text { your co- workers }\end{array}$ & $\begin{array}{c}4 \\
(8 \%)\end{array}$ & $\begin{array}{c}16 \\
(32 \%)\end{array}$ & $\begin{array}{c}19 \\
(38 \%)\end{array}$ & $\begin{array}{c}7 \\
(14 \%)\end{array}$ & $\begin{array}{c}4 \\
(8 \%)\end{array}$ \\
\hline $\begin{array}{l}\text { Are you facing } \\
\text { psychological } \\
\text { issues like stress, } \\
\text { sleeping } \\
\text { problems, } \\
\text { irritability, etc., }\end{array}$ & $\begin{array}{c}11 \\
(22 \%)\end{array}$ & $\begin{array}{c}17 \\
(34 \%)\end{array}$ & $\begin{array}{c}14 \\
(28 \%)\end{array}$ & $\begin{array}{c}8 \\
(16 \%)\end{array}$ & $\begin{array}{c}0 \\
(0 \%)\end{array}$ \\
\hline Total & 62 & 128 & 65 & 31 & 4 \\
\hline Mean & 10 & 21.3333 & 13 & 5.1 & 0.66 \\
\hline Median & 25.9140 & 19 & 14 & 5 & 0 \\
\hline St.dev & 41.8724 & 7.55424 & 5.0990 & 2.1 & 1.63 \\
\hline $\begin{array}{l}\text { Average } \\
\text { Deviation }\end{array}$ & 5.11111 & 6.89605 & 4.5607 & 1.9 & 1.49 \\
\hline Chi Squared Test & \multicolumn{4}{|c|}{$3.27395 \mathrm{E}-08$} & \\
\hline
\end{tabular}

Statistical test: Chi-square test was used for above table.

\section{Research Hypothesis $\left(\mathrm{H}_{1}\right)$}

There is a significant association between the psychological factors of the respondents.

\section{Null Hypothesis $\left(\mathbf{H}_{0}\right)$}

There is no significant association between the psychological factors of the respondents. Since 3.27395E-08 $<0.05$, therefore we reject the null hypothesis and accept the research hypothesis thereby conclude that government school teachers are facing psychological stress, it is suggested that teachers should be given more counselling to get over the stress on their job.

\section{B. Impact of psychological issues faced by Government school teachers using One Factor ANOVA}

Table No.2

\begin{tabular}{|l|l|l|l|l|l|l|}
\hline $\begin{array}{l}\text { Source of } \\
\text { Variation }\end{array}$ & SS & Df & MS & F & P-value & F crit \\
\hline Between & 1471.6 & 4 & 367. & 12.7 & $8.54 \mathrm{E}-06$ & 2.75871 \\
Groups & 66667 & & 9167 & 6897 & & \\
\hline Within & 720.33 & 25 & 28.8 & & & \\
Groups & 33333 & & 1333 & & & \\
\hline Total & 2192 & 29 & & & & \\
& & & & & & \\
\hline
\end{tabular}

\section{Statistical test: One way ANOVA}

We have statistically significant evidence and conclude that there is a mean psychological stress faced by the government school teachers. Hence the calculated value is greater than the table value $(12.76897>2.75871)$ so the research hypothesis rejected and the null hypothesis is accepted.

\section{Statistical Tools Used- Average, Median, Standard}

Deviation and Standard Deviation Average.

From the above data it's clear, the factors affecting stress level of teachers are evaluated on the above table, data's are collected from 50 government school teachers working in and
Source: Primary Data

around Kumbakonam, and from the data we can find that $42 \%$ of the teachers are agreeing that they are having issues by the technical changes in education. Secondly $26 \%$ of the responded have stated that they are not psychological stressed. $20 \%$ of government school teachers strongly agreed that they are facing psychological issues in their work life. When compared from this table only $10.2 \%$ of people disagreed that they are not stressed in their job nature. As well as just $1.03 \%$ government school teachers strongly disagreed and saying they are enjoying the structure of Tamil Nadu government education system.

\section{Fig. No.1}

Emotional problems faced due to changes in
government policies on teaching up gradation

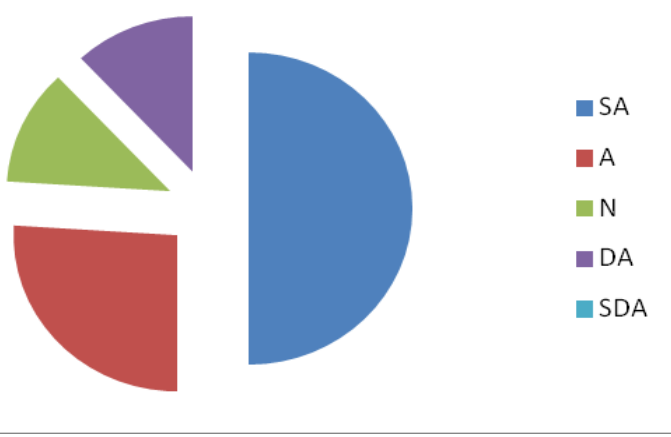

The above figure 1 represents the emotional problems faced by the government school teachers due to changes in government policies on teaching up gradation. In late 80 's and 90 's every graduate barely believes teaching profession is one of the easiest job with more remuneration. As well as overall $60 \%$ of government school teachers strongly agreed the statement that they are facing emotional problems from the government policies. And 32\% of government school teachers agreed the statement mentioned above. $12 \%$ of teachers said they are neutral in facing emotional stress due to these policies. Moreover $14 \%$ of government school teachers stated that they are not facing such emotional problems in their work life.

Fig. No. 2

\section{Stress on degradation from higher level education to lower level education}

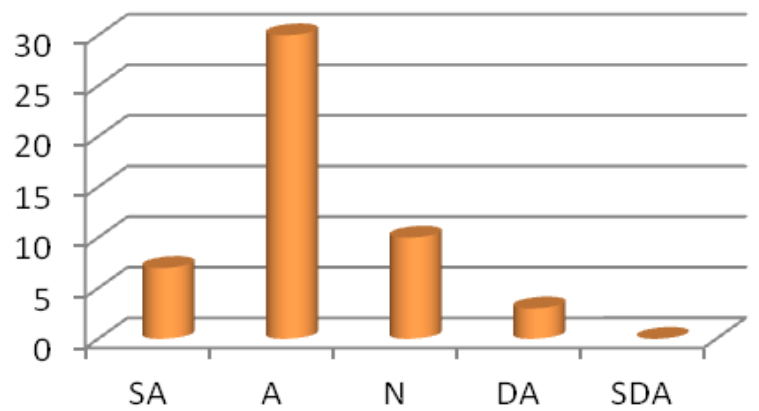

The above figure 2 represents the psychological stressed faced by the government school teachers from the degradation

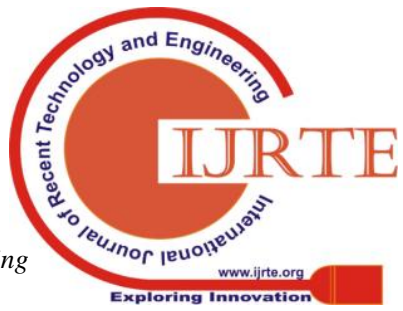




\section{Psychological issues faced by Government School Teachers on upgradation of technological and teaching techniques with special reference to Kumbakonam}

on job from the higher level to the lower level. Every job has its nature of stress to full fill the work in their space. As well as overall $60 \%$ of government school teachers strongly agreed the statement that they are facing emotional problems from the government policies. And 32\% of government school teachers agreed the statement mentioned above. $12 \%$ of teachers said they are neutral in facing emotional stress due to these policies. Moreover 14\% of government school teachers stated that they are not facing such emotional problems in their work life.

\section{Fig. No.3}

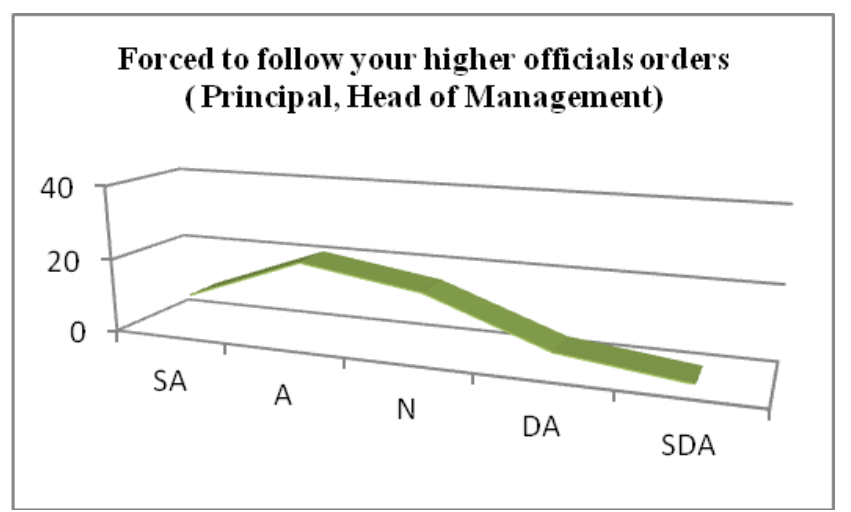

The above figure 3 describes the psychological stress from the orders of the higher officials like (Principal, Head of Management) of the government school teachers. As well as overall $60 \%$ of government school teachers strongly agreed the statement that they are facing emotional problems from the government policies. And 32\% of government school teachers agreed the statement mentioned above. $12 \%$ of teachers said they are neutral in facing emotional stress due to these policies. Moreover 14\% of government school teachers stated that they are not facing such emotional problems in their work life.

\section{Fig. No.4}

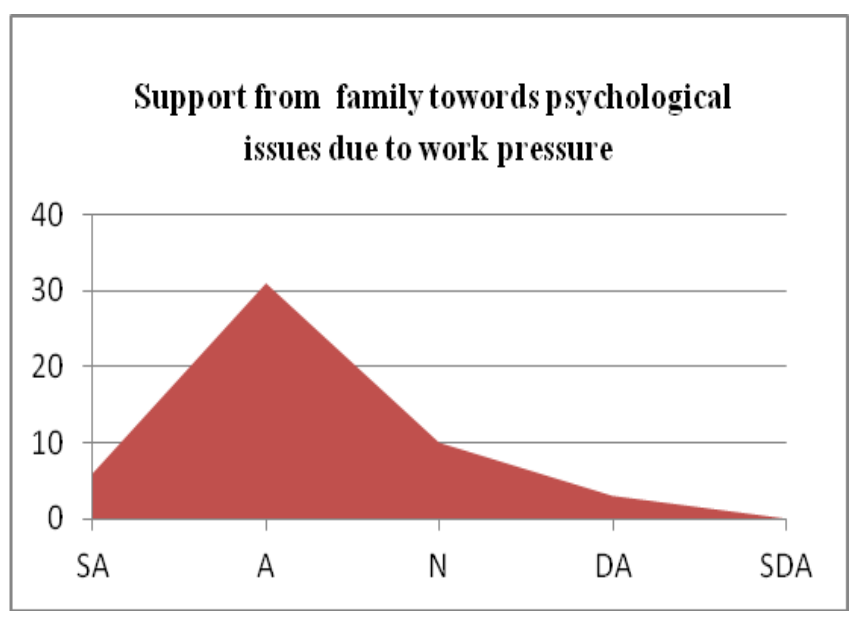

The above figure 4 expresses the support of family on psychological issues due to work pressure. Family is a place where we can relieved from all type of stress from the work place. Here $75 \%$ of government school teachers strongly agreed that their family merely supporting them to overcome the work pressure. $5 \%$ of teachers neural in this statement, and $4 \%$ agreed this statement. Government school teachers doesn't choose disagree or else strongly disagree to this statement, this shows how they are affectionate from their family side to overcome the psychological problems.

Fig. No.5

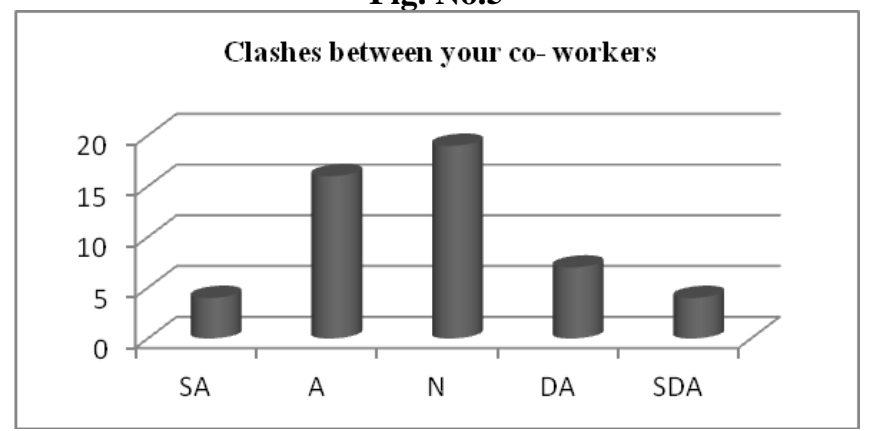

The above figure 5 explains the statement clashes' arising between co- workers, mainly considering this diagram it clearly present that $75 \%$ of people stated neutral. And also $65 \%$ of respondents agreed this statement, $35 \%$ of government school teachers disagreed that they stated they are not facing clashes' with their co- workers. $24 \%$ strongly agreed and $21 \%$ strongly dis agreed this statement. From this, it's clear that they facing clashes but that not lasted longer. Clashes between co- workers may pay stress and tension when facing them.

Fig. No. 6

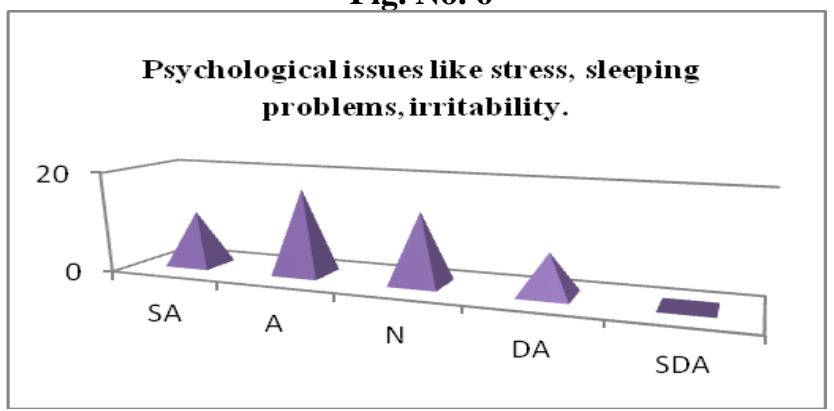

From the above analyzed cone diagram, represents whether they facing psychological issues like stress, sleeping problems, irritability, etc. Mainly $65 \%$ of government school teachers agreed that they are facing psychological issues in their work place. $60 \%$ of respondents stated they are neutral in facing the stress, and $45 \%$ of people agreed they are facing more psychological issues. Only $30 \%$ of government school teachers disagreed and also stated that they are not facing such problems in their work place.

\section{Analysis on reason for Stress faced by Government school teachers using One Factor ANOVA}

Table No. 3

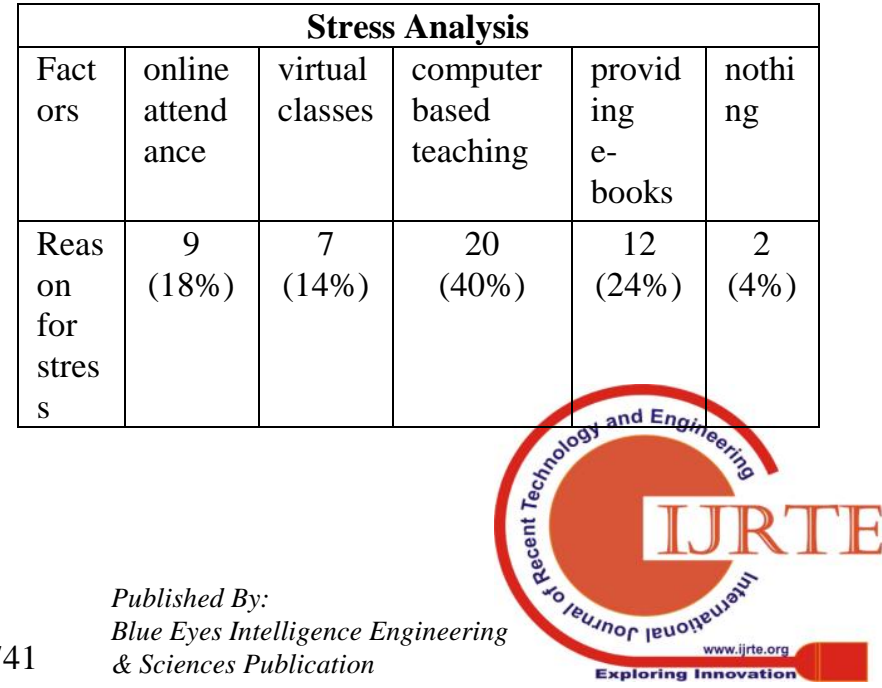




\section{ONE FACTOR ANOVA}

Table No. 4

\begin{tabular}{|l|r|r|r|r|}
\hline $\begin{array}{c}\text { Source of } \\
\text { Variation }\end{array}$ & SS & df & MS & \multirow{2}{*}{ F } \\
\hline Between Groups & 178 & 4 & 44.5 & \multirow{2}{*}{6} \\
\cline { 1 - 2 } Within Groups & 0 & 0 & 65535 & \multirow{2}{*}{65535} \\
\cline { 1 - 2 } Total & 178 & 4 & & \\
\hline
\end{tabular}

Statistical test: One way ANOVA "f" test was used for the above hypothesis

We have statistically significant evidence and conclude that there is a mean psychological stress faced by the government school teachers. Hence the calculated value is 65535 , so the research hypothesis rejected and the null hypothesis is accepted.

From the above data we can understand what the factors are giving more stress to government school teachers. We can find that $60 \%$ of the teachers are stated that computer based teaching has giving more stress than any other factor. Secondly $45 \%$ of the respondent have stated that they are psychological stressed due to providing e- books to the students. $20 \%$ of government school teachers stated that they are facing psychological issues in their work by uploading online attendance. When compared from this table only $10.2 \%$ of people stated that they are stressed due to virtual classes. As well as just $1.03 \%$ government school teachers stated that they are not facing any stress due to these factors in their work life.

Fig. No.7

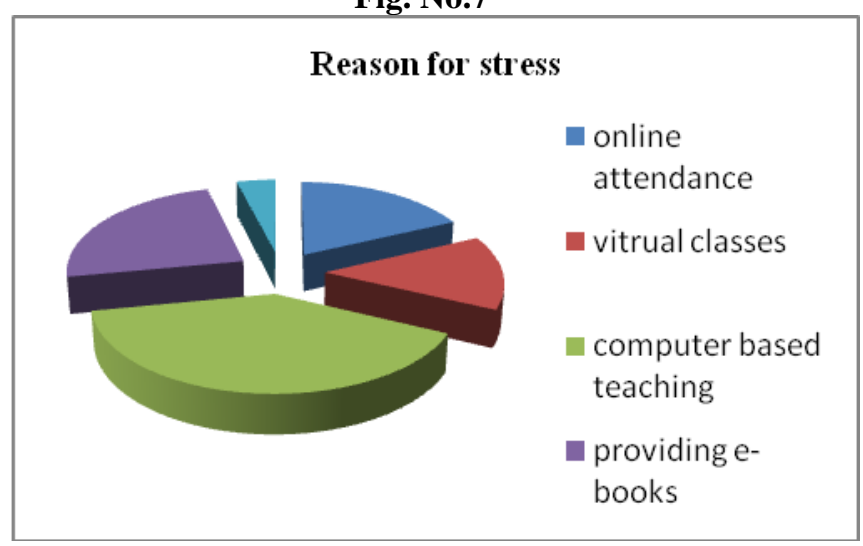

The above figure 7 explains the sources which giving more stress to government school teachers to handle. With the comparison, it's clear mostly $65 \%$ of respondent denoted computer based teaching is giving more psychological issues to them and $40 \%$ of government school teachers stated that providing e-books is giving more stress. Teaching techniques is developing day by day, from smart classes to Skype classes but $40 \%$ of government school teachers agreed that updating attendance in online in correct time is more stressful in their job. 35\% of people denoted virtual classes is more stressful, $3 \%$ of government school teachers stated that there is not any stressful teaching techniques in government schools.

\section{FINDINGS}

Above $75 \%$ of government school teachers are facing more psychological issues in their work life due to technological up gradation.

$>$ Mostly $60 \%$ of respondents are strongly agreed that they are emotionally stressed due to changes in government policies on teaching up gradation.

$>$ Nearly $80 \%$ of government school teachers are psychologically stressed on degradation from higher level education to lower level education.

$>$ Majority of $55 \%$ government school teachers agreed that they are forced to follow forced to follow your higher officials orders ( Principal, Head of Management)

$>$ Mainly most of government school teachers trying to overcome the stress with the help of their family and friends.

$>$ Nearly $60 \%$ of respondents stated they are facing clashes with their co- workers with neural appropriation.

$>$ Overall $65 \%$ of government school teachers agreed that they are facing psychological stress like sleeping problems, head ache, depression.

$>$ More over $75 \%$ of government school teacher stated computer based teaching is most stressful teaching method.

\section{CONCLUSION}

In every job we have to face stress, but teaching is a job where the teacher should free mind to teach the students with their knowledge. With new teaching technologies and teaching techniques government school teachers are facing more stress to adapt themselves for the future society. Government should enforce more awareness and training programmes to government school teachers that they can overcome the stress issues and also counselling from psychiatrists' like corporate can help those government school teachers to relive from psychosomatic stage. Government must improve the technological tools and modern techniques to guide the government students with futuristic education; by the way government schools should come over the dynamic changes and must take over the private schools education module to create new form of smart education

\section{REFERENCES}

1) Mehra, P., \& Mital, M, "Integrating technology into the teaching-learning transaction: Pedagogical and technological perceptions of management faculty". International Journal of Education and Development using ICT, 3(1), 2007.

2) Burke, R. J., \& Greenglass, E, "Work stress, role conflict, social support, and psychological burnout among teachers", Psychological reports, 73(2), 1993, 371-380.

3) Desouza, J. M. S., Boone, W. J., \& Yilmaz, O, “A study of science teaching self-efficacy and outcome expectancy beliefs of teachers in India", Science Education, 88(6), 2004, 837-854.

4) Bibou-Nakou, I., Kiosseoglou, G., \& Stogiannidou, A. A, "Elementary teachers' perceptions regarding school behavior problems: Implications for school psychological services", Psychology in the Schools, 37(2), 2000, 123-134.

5) Bartholomew, K. J., Ntoumanis, N., Cuevas, R., \& Lonsdale, C., “Job pressure and ill-health in physical education teachers: The mediating role of psychological need thwarting", Teaching and Teacher Education, 37, 2014, 101-107

6) Mahmood, A. S., Khattak, N., Haq, N., \& Umair, S., "Technology Integration and Upgradation of Higher Secondary Education: Need of the Hour in Pakistan", Handbook of 
Research on Mobile Devices and Smart Gadgets in K-12 Education, 2018, pp. 115-133. IGI Global.

7) Keswani, B., Banerjee, C., \& Patni, P, "Role of Technology in Education: A 21st Century Approach", Proceedings of second national conference on challenges and opportunities in information technology, 2008 .

8) Sharma, R, "Schools in the changing Times: Framework for Innovations in Schools, beyond Studies", International Journal of Learning, 16(12), 2010.

9) Saravanabhavan, S., \& Saravanabhavan, R. C, "Knowledge of learning disability among pre-and in-service teachers in India", International Journal of Special Education, 25(3), 2010, 132-138.

10) Muralidharan, K., \& Sundararaman, V, "Teacher performance pay: Experimental evidence from India", Journal of political Economy, 119(1), 2011, 39-77. 